\title{
Twenty years: a very short sequence in the RNA world
}

\author{
BRENDA L. BASS \\ Department of Biochemistry, University of Utah, Salt Lake City, Utah 84112-5650, USA
}

Lucky for me, my scientific career has encompassed the entire "official" history of the RNA journal and the RNA Society: ribozymes to miRNAs to lncRNAs; Northern blots to PCR to deep sequencing; nuclease structure probing to crystallography to cryo-electron microscopy. Of course, I wasn't there at the very beginning - the RNA world rumbled for quite a while before the Society erupted.

At the time, some of the RNA world's rumblings were hard to understand. Why were mutations that affected the function of the ribosome in the RNA, not the protein? What!?-You think you can predict the stability of an RNA stem just by adding the free energies of nearest neighbor base pairs? Why was messenger RNA missing sequences that existed in the DNA encoding it? What ARE all of those small nuclear RNAs? You're telling me it does that without protein! Whoa, RNARNA base pairing between those snRNAs and mRNA is required for splicing out those missing pieces!!

The various RNA world rumblings ultimately resulted in the RNA Processing meeting, held at Cold Spring Harbor Laboratory (CSHL), and this meeting was the precursor to today's RNA Society meeting. The very first talk I gave in my scientific career was at the RNA Processing meeting in an old CSHL auditorium that is no longer used. I was in a cast, having recently hurt my knee skiing. The weather was cold so I wore long pants over my full-length walking cast, and for years, many RNA scientists thought I had a permanent disability. (At the banquet, the late David Apirion told me sweetly that he didn't know what was wrong with me, but if I had been able to dance, he would have asked me.) The official CSHL pointer at the time was an $\sim 20$-foot-long bamboo pole that tapered at the end. I remember holding on tightly to the podium in hopes that me and my cast would not topple over and watching the end of the pole wave wildly as it transmitted the impulse from my shaking hands.

In those days women scientists were fewer, and we were all housed in the "Hooper" dormitory, where Barbara McClintock had an apartment on the ground floor. One morning I came out of the building and there she was, just standing in the yard. I still kick myself that as an inexperienced young

Corresponding author: bbass@biochem.utah.edu

Article and publication date are at http://www.rnajournal.org/cgi/doi/ 10.1261/rna.050856.115. Freely available online through the RNA Open Access option. graduate student I didn't have the nerve to talk to this legend, since I never was presented with this opportunity again.

Hooper was an old building, and typically we did not lock the doors to our dorm rooms; in fact, I don't remember even having a key. However, one year, for reasons that are unclear, something changed. I don't remember whether we were given keys, but I do know that we were not informed that the doors would lock behind us. This of course led to a number of scientists returning to their rooms after their showers, in their towels, only to find that they were locked out of their rooms. For the next part of the story I do not know the truth from the urban legend. But what I heard (amidst lots of giggles) was that when one of our most loved and esteemed Society members was caught in the hall in her "skivvies," the problem was quickly taken care of by an esteemed CSHL resident who was NOT a member of the RNA Society. What I do know for certain is that when we all returned to our rooms that night, the lock on each and every room was carefully taped to the open position.

Yup, there was a lot of history before the RNA Society finally erupted. In fact, the dawn of the RNA Society and its journal was not a precise moment, but began with subtle rumblings that a few, and then many, could feel. (I should note that there are true and indisputable facts in this article, although this is clearly a biased history. While I decided not to use names of the living, suffice it to say, you will know who you are and are welcome to reveal yourself to your colleagues.)

\section{Future RNA Society member \#1:}

Do you think we should become a society?

\section{Future RNA Society member $\# 2$ :}

Come on, whoever heard of a society based on a $2^{\prime}$ hydroxyl?

\section{Future RNA Society member \#1:}

Well, you know, there's a society based on the peptide bond.... and isn't there one for a fungus?

(c) 2015 Bass This article, published in $R N A$, is available under a Creative Commons License (Attribution-NonCommercial 4.0 International), as described at http://creativecommons.org/licenses/by-nc/4.0/. 


\section{Future RNA Society member \#2:}

I think the fungus one has a broader goal, and anyway, two wrongs don't make it right.

\section{Future RNA Society member \#1:}

But, but...wait a minute...if we became a society then we could have our own journal!! We could publish our papers!

And so it began. Our dreams came true, and indeed, we can now publish our papers. Um, well, our very good papers at least. Fortunately, from the very first issue, $R N A$ has had high standards, but in a refreshingly non-political and democratic way. Of course, nothing is perfect, and I am sure there are times when mistakes are made. But thanks to the careful attention of Tim Nilsen and the Editors, in the large majority of cases, if you submit a good paper and address the constructive criticisms, your paper will be published in RNA. And most importantly, your paper will be READ. Time and again I hear RNA Society members say that they "read" RNA. Trust me, it is not common for scientists to "read" a journal these days. We search the web, find the papers we are interested in from the huge selection of papers available online, and download the PDF file. That many of us "read" RNA is a testament to its quality, and the large number of papers we find of interest in a single issue of the journal. Our dreams came true: We have a one-stop shop for RNA science.

I like to think that RNA reflects the RNA Society. The review process is largely a humane one, and I have always thought that for a bunch of competitive scientists, RNA Society members are more humane than most (Ha! The Humane Society!). Seriously, I truly feel that there are moments of compassion and caring. Further, I think scientific role models among our established RNA Society members help nurture high scientific and ethical standards in our more junior members. This happened for me as a young scientist, and I thank all of the people involved (with no blame at all if things did not quite turn out the way you intended).
But the meeting is not small like it was at the start of my career, so maintaining these lofty goals, and the ideal RNA Society, will likely take some conscious effort. However, if we all do our part, my guess is that the solid foundation will stand. Of course, if you don't have the same warm and fuzzy view of the RNA Society that I do, or you envision a different Society, as an RNA Society member you have the ability to change things.

But back to the journal. While we all should be immensely proud of $R N A$, these are tough, extremely competitive, times. When funding is on the line, it is hard not to do anything you can to push to the front of the line. (But, really-is this how you want to live your life?) So, we need to be extra vigilant to keep the standards of our journal high, while continuing to conduct the review process in a non-political and democratic manner. We need to pay attention to things that are beginning to affect the review process of all journals. Always imagine you are reviewing your own paper: Be critical, but respectful. Certainly we need to give our trainees the opportunity to help review papers; this is part of the learning process, and more often then not, they come up with the important details. But don't let that review go out the door with a long list of your graduate student's criticisms that you haven't carefully considered. Importantly, when faced with the opportunity to cite either a poor quality paper from one of those "prestigious" journals or the excellent paper that was published in $R N A$, cite the RNA paper! In fact, go out of your way to appropriately cite your colleagues' excellent $R N A$ papers!

I am so proud of the RNA Society and what it stands for. I am so glad to have the RNA journal, and so, so, grateful to those who have put in time as editors. I have always felt the RNA Society is my society, and I so hope you feel it is yours. If not, I hope you make it so.

\section{Acknowledgments}

Thanks to my colleagues D. Cazalla and J. Whipple for reading this piece and offering helpful suggestions. 

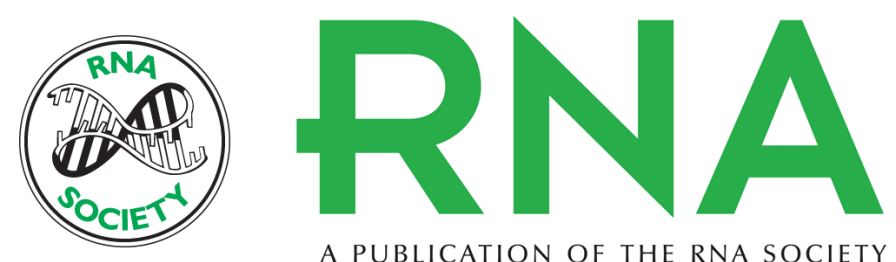

A PUBLICATION OF THE RNA SOCIETY

\title{
Twenty years: a very short sequence in the RNA world
}

\author{
Brenda L. Bass
}

RNA 2015 21: 490-491
Open Access Freely available online through the RNA Open Access option.
Creative This article, published in $R N A$, is available under a Creative Commons License Commons (Attribution-NonCommercial 4.0 International), as described at License http://creativecommons.org/licenses/by-nc/4.0/.

Email Alerting Receive free email alerts when new articles cite this article - sign up in the box at the Service top right corner of the article or click here. 